\title{
DETERMINANTY ZAUFANIA DO TECHNOLOGII
}

\author{
Joanna Ejdys
}

\section{Wprowadzenie}

W związku z pojawianiem się zjawisk i konstruktów trudnych do wytłumaczenia tylko i wyłącznie w kontekście racjonalności działania dominujący w naukach o zarządzaniu paradygmat funkcjonalistyczny coraz częściej jest podważany. Jednym z takich konstruktów jest zaufanie, które dokładnie wpisuje się w zmianę paradygmatu i odzwierciedla coraz powszechniejsze skupianie się na wymiarze kulturowym i życiu codziennym (Sztompka, 2007). Brak jednoznacznej definicji zaufania (Rousseau $\mathrm{i}$ in., 1998) wynika przede wszystkim z wielowymiarowości, złożoności i wieloaspektowości (multi-faced) analizowanego pojęcia. Zaufanie jest podstawą stosunków społecznych (Luhmann, 1979), ważnym elementem budowania relacji społecznych (Larzelere, Huston, 1980) i tworzenia kapitału społecznego (Mayer i in., 1995). Coraz częściej natomiast kategoria zaufania odnoszona jest do systemu społeczno-technologicznego, w którym relacje występujące między ludźmi często zastępowane są przez relacje pomiędzy człowiekiem a technologią, od których to technologii człowiek staje się uzależniony.

Termin zaufanie jest obiektem zainteresowania przedstawicieli, między innymi, takich dyscyplin naukowych, jak: filozofia, socjologia, ekonomia, nauki o zarządzaniu, psychologia, nauki o polityce czy coraz częściej dyscyplin z nauk technicznych (zaufanie do technologii). Ukierunkowanie zaufania na obiekty techniczne spowodowało zainteresowania badaczy terminem zaufania do technologii (technology trust) i próbą jego operacjonalizacji, przejawiającą się w poszukiwaniu odpowiedzi na pytania: Jak definiować zaufanie do technologii? Co determinuje zaufanie do technologii? Czy i jak je mierzyć?

Bez wątpienia jedną $\mathrm{z}$ podstawowych przyczyn pojawienia się kategorii zaufania do technologii jest dynamiczny rozwój technologii, z jednej strony determinujący rozwój społeczno-gospodarczy, $z$ drugiej będący źródłem trudnych do przewidzenia skutków (w krótkiej i długiej perspektywie czasowej) (Wasiluk, Suchocki, 2012; Ejdys i in., 2013).

W życiu codziennym coraz powszechniejsze stają się rozwiązania technologiczne, które ograniczają, zastępują lub eliminują udział człowieka. Dotychczasowe relacje człowiek-człowiek zostają zastępowane relacjami człowiek-technologia. Przykład stanowią automatyczne kasy w hipermarketach, gdzie klient sam może dokonać płatności za swoje zakupy, odkurzacze, które o określonej godzinie rozpoczynają sprzątanie pomieszczeń według zaprogramowanej we własnym zakresie trajektorii, roboty asystujące w domach opieki społecznej w spacerach osób starszych czy przenoszące osoby chore $\mathrm{z}$ jednego miejsca w drugie, urządzenia dekoracyjne pomieszczeń przypominające o konieczności zażycia leku przez osoby $\mathrm{z}$ problemami z pamięcią, aplikacje mobilne na smartfony umożliwiające monitorowanie podstawowych funkcji życiowych (ciśnienie, puls, poziom cukru, ale również poziom stresu) czy stylu życia (diety) oraz Internet rzeczy pozwalający na budowę „inteligentnych domów” wyposażonych $\mathrm{w}$ sensory, odbiorniki umożliwiające komunikację z „domem” z odległych miejsc za pomocą Internetu. Coraz powszechniej stosowaną praktyką są również systemy pozwalające na przesyłanie pozyskanych danych np. o stanie zdrowia do lekarza czy pielęgniarki, informujące o zbliżającym się pogorszeniu stanu zdrowia. W dalszym ciągu wyzwanie stanowi umiejętność gromadzenia danych i uczenia się urządzeń na podstawie zgromadzonych danych, co pozwoliłoby na podejmowanie właściwszych decyzji czy przewidywanie przyszłych stanów (Hiltunen, Hiltunen, 2015; Nazarko, Kononiuk, 2013). 
W artykule autorka podjęła próbę zdefiniowania zaufania do technologii, opisu dwóch kluczowych warunków wymagających zaufanie do technologii (ryzyko i zależność) oraz wskazania determinant zaufania do technologii. Podstawową metodą badawczą był przegląd literatury i krytyczna analiza piśmiennictwa. Przeprowadzony przegląd literatury pozwolił na wskazanie potencjalnych obszarów badawczych w tym zakresie.

\section{Zaufanie do technologii}

W Słowniku Języka Polskiego (2006) zaufanie zostało zdefiniowane jako przekonanie, że:

- jakiejś osobie lub instytucji można ufać;

- czyjeś słowa, informacje są prawdziwe;

- ktoś posiada jakieś umiejętności i potrafi je odpowiednio wykorzystać.

Przytoczona definicja zaufania stanowi przykład wąskiego rozumienia pojęcia zaufanie, odnoszącego się tylko do cechy przypisanej człowiekowi, relacjom międzyludzkim lub instytucjom. Natomiast Wielki Słownik Języka Polskiego (2016) nie zawęża już znaczenia terminu zaufania, definiując je jako „przeświadczenie, że można komuś lub czemuś ufać". W polskiej literaturze przedmiotu obszerny przegląd definicji zaufania znaleźć można w publikacjach autorów: J. Paliszkiewicz (2013), A. Sankowska (2015), W.M. Grudzewski i inni (2009), K. Krot, D. Lewicka (2016), U. Ryciuk (2016).

Przykładowo J. Paliszkiewicz (2013) definiuje zaufanie: wiara, że druga strona nie będzie działała przeciwko nam, będzie działała w sposób, który jest dla nas korzystny, będzie wiarygodna, będzie zachowywała się w sposób przewidywalny i zgodny z powszechnie przyjętymi normami. Według F. Fukuyamy (1997), zaufanie to mechanizm oparty na założeniu, że innych członków danej społeczności cechuje uczciwe i kooperatywne zachowanie, mające swoje źródło we wspólnie wyznawanych normach.

W większości stosowanych definicji zaufania wskazać można dwa podstawowe konstrukty: (i) intencja, przejawiająca się w dobrowolnej chęci być pod wpływem, zależnym od drugiej strony; (ii) przekonanie/wiara oznaczająca, że jedna ze stron wierzy w życzliwość, kompetencje, szczerość oraz przewidywalność sytuacji. P. Sztopmka (2007) nadał zaufaniu dodatkową cechę. W jego ujęciu zaufanie to „coś więcej, niż tylko bierne rozważania przyszłych możliwości”. Według autora, zaufanie to oparte na przekonaniu działanie, co oznacza, że dopiero podejmowane $\mathrm{w}$ warunkach niepewności działania przez stronę ufającą są dowodem zaufania pokładanego w drugiej stronie relacji.

Początkowo relacje oparte na zaufaniu odnosiły się do związków międzyludzkich, czyli występujących w kontaktach między dwoma lub więcej osobami (interpersonal trust). Z czasem pojęcie zaufania zostało odniesione do instytucji/organizacji (institutional trust, organizational trust), rzeczy, urządzeń oraz technologii (technology trust).

W relacji człowieka z obiektami materialnymi/technologiami pojawiają się dwie kategorie obiektów obdarowujących zaufaniem. $Z$ jednej strony jest to twórca technologii, który wierzy, że technologia przez niego zaprojektowana będzie spełniała określone funkcje i role społeczne, $\mathrm{z}$ drugiej strony występuje użytkownik technologii, posiadający wiarę i przekonanie, że technologia spełni jego oczekiwania. Można zatem mówić, o „pozornym zaufaniu” człowieka (użytkownika) do technologii (rys. 1).

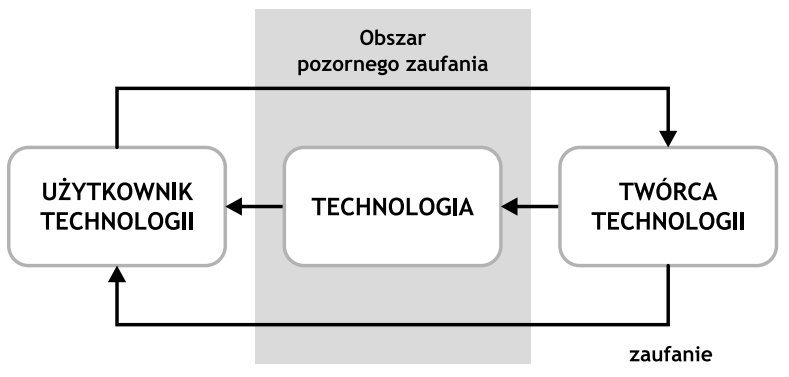

Rys. 1. Relacja dwustronna oparta na zaufaniu pomiędzy użytkownikiem i twórca technologii

Źródto: opracowanie wtasne

Jedną z pierwszych definicji zaufania do technologii opracowała S.K. Lippert (2001), wskazując, że zaufanie do technologii wyraża gotowość jednostki do bycia pod wpływem technologii, wynikającą z oczekiwanej przewidywalności, wiarygodności i użyteczności technologii oraz indywidualnego upodobania technologii. P. Sztompka (2007), wyróżniając zaufanie do systemów technicznych, wprowadził pojęcie zaufania technologicznego, ale odnoszącego się nie bezpośrednio do samego systemu, ale do ludzi, którzy go zaprojektowali, obsługują czy nadzorują jego funkcjonowanie. Według autora, zaufanie technologiczne to oczekiwanie sprawności, niezawodności i skuteczności urządzeń i systemów technicznych, poprzez pryzmat osób, twórców danej technologii/obiektów materialnych.

Coraz powszechniejsze jednak przypisywanie technologiom użytkowym cech charakterystycznych dla relacji człowiek-człowiek, np. zapewnienie poczucia bezpieczeństwa, wiarygodności, rzetelności, lojalności, dokładności, w opinii autorki artykułu pozwalają na stosowanie terminu zaufania, również w odniesieniu do rzeczy martwych. Według wielu autorów, zaufanie do technologii jest szczególnym typem zaufania, którym użytkownik technologii (człowiek) obdarza zaufaniem „nieożywioną” technologię (Lippert, Forman, 2006; Xu i in., 2014). Niezbędne jest jednak wypracowanie odmiennych kryteriów pomiaru zaufania do technologii. Wykorzystywane na potrzeby pomiaru zaufania interpersonalnego konstrukty pomiarowe, takie jak: uczciwość, wiarygodność, lojalność, kompetencje czy życzliwość, muszą zostać zastąpione innymi, z uwagi na brak możliwości obdarzania rzeczy martwych uczuciami, emocjami.

N. Lankton i inni (2014) wyróżnili trzy cechy zaufania do technologii, odnosząc je do cech zaufania interpersonalnego (rys. 2). Uzasadniając trzy cechy zaufania do technologii, autorzy wskazali, że celem ukazania swoich kompetencji człowiek wykonuje zadania dobrze, doradza innym lub podejmuje trafne decyzje. Systemy techniczne, obejmujące również technologię, nie mogą realizować całości zadania, a jedynie zapewniają 
funkcjonalność wymaganą dla użytkowników w celu realizacji zadań. Przykładowo oprogramowanie stosowane w organizacji nie zrealizuje zadania, a jedynie może stanowić narzędzie pomocne przy jego realizacji przez człowieka. Człowiek okazuje swoją uczciwość/prawość poprzez zaangażowanie, mówienie prawdy czy bycie wiarygodnym w oczach innych. Sednem uczciwości jest to, że człowiek powinien robić to, co mówi, i wtedy ludzie polegają na takiej osobie. Systemy techniczne z założenia nie mogą dotrzymywać obietnic. Systemy techniczne mogą okazywać swoją „uczciwość” poprzez zapewnienie funkcjonalności zgodnie z zaprojektowanymi możliwościami, w sposób niezawodny i ciągły (niezawodność). Człowiek okazuje swoją życzliwość poprzez działanie w najlepszym interesie drugiej strony, poprzez okazywanie troski, niesienie pomocy i wsparcia. Technologia nie posiada takich zdolności i ludzkich motywów i nie czuje odpowiedzialności. Technologia nie może być życzliwa, ale może odpowiadać na potrzeby i oczekiwania użytkowników i tym samym stanowić wsparcie dla użytkowników.

Uwzględniając specyficzny rodzaj relacji człowieka z technologią, można wyróżnić dwie charakterystyczne cechy zaufania do technologii. Pierwsza związana jest z postrzeganymi przez potencjalnych użytkowników cechami technologii, jej funkcjonalnościami; druga $\mathrm{z}$ deklarowaną chęcią polegania na technologii (bycia zależnym), wynikającą właśnie $\mathrm{z}$ posiadanych przez technologie pożądanych cech. Autorka zaproponowała następującą definicję zaufania do technologii: wynikająca $z$ postrzeganych właściwości technologii oraz czynników otoczenia skłonność do polegania na technologii, w sytuacji potencjalnego ryzyka związanego z użytkowaniem technologii, determinująca intencje w zakresie przyszłego wykorzystywania technologii. Skłonność do polegania na technologii wynika przede wszystkich z oczekiwanej jej funkcjonalności, niezawodności i systemu wsparcia. W świetle przyjętej definicji skale pomiarowe zaufania do technologii najczęściej odzwierciedlają następujące cechy i funkcje technologii: zawierzenia technologii w sytuacjach ważnych, krytycznych, problemowych; przewidywalności technologii, funkcjonowania technologii zgodnie z oczekiwaniami użytkowników, działania technologii w interesie użytkowników, poczucia bezpieczeństwa gwarantowanego przez technologię, świadczenia pomocy w razie problemów użytkowników.

Przejawem stale rosnącego zainteresowania badaczy tematyką zaufania do technologii jest liczba publikacji w bazach bibliograficznych. W wyniku wyszukiwania w bazie SCOPUS słów „technology” i „trust”, występujących równocześnie w tytule, słowach kluczowych lub abstrakcie, zidentyfikowano 12139 dokumentów (rys. 3).

Zaufanie do technologii może być odnoszone do poziomu ogólnego, odzwierciedlającego poziom zaufania społecznego lub do poziomu konkretnej technologii, konkretnego rozwiązania. Cykliczne, ogólnoświatowe badania prowadzone przez Institute for Comparative Survey Research z siedzibą w Wiedniu potwierdzają zróżnicowany poziom „zaufania do technologii” jako czynnika poprawiającego jakość i komfort życia. Na rysunkach 4 i 5 zaprezentowano wyniki potwierdzające, w jakim zakresie społeczeństwa badanych krajów postrzegają pozytywny wpływ nauki i technologii na życie. Analiza wyników pozawala stwierdzić, że społeczeństwo polskie należy do grupy, którą charakteryzuje relatywnie wysoki poziom zaufania do technologii jako czynnika sprawiającego, że nasze życie jest zdrowsze, łatwiejsze i bardziej komfortowe (rys. 4) oraz wiara, że dzięki nauce i technologii świat jest lepszy (rys. 5). Ważnym obszarem badawczym wydaje się badanie czynników determinujących zaufania ogólne i przyczyny jego zróżnicowania oraz dynamikę zmian w czasie.

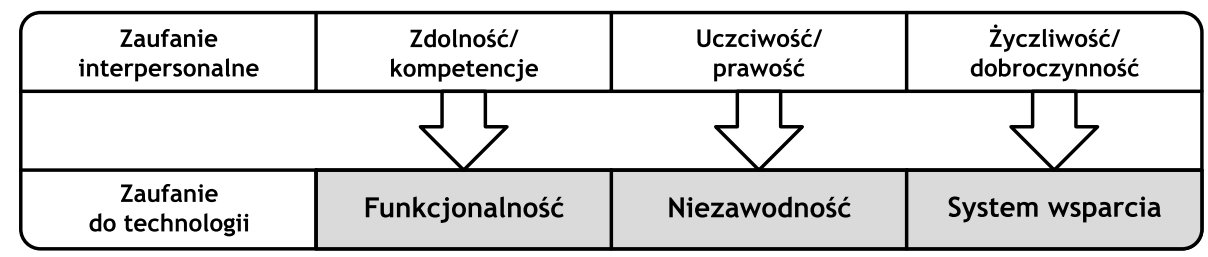

Rys. 2. Cechy zaufania do technologii w kontekście cech zaufania interpersonalnego Źródto: opracowanie własne na podstawie (Lankton i in., 2014)

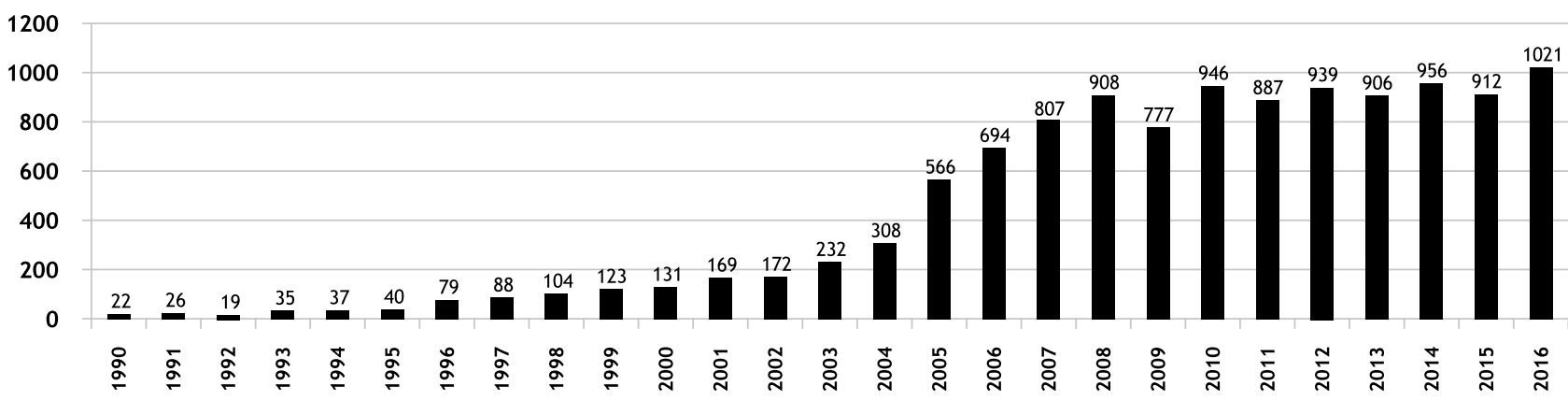

Rys. 3. Liczba publikacji w bazie SCOPUS opublikowanych w latach 1990-2016 na bazie wyszukiwania wedtug stów „technology” $i$,trust” zawartych w tytule lub abstrakcie lub stowach kluczowych artykutu, data dostępu: 5.03.2017 r.

Źródto: opracowanie wtasne 


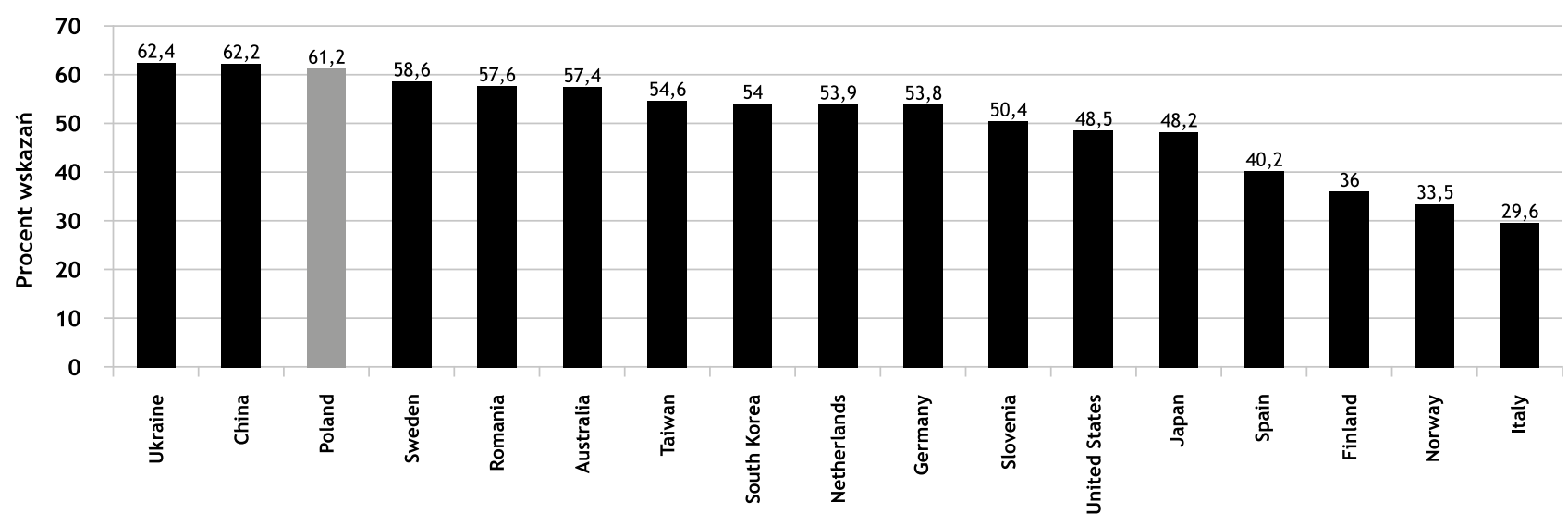

Rys. 4. Procent wskazań odpowiedzi na pytanie: Nauka i technologie sprawiaja, że nasze życie jest zdrowsze, tatwiejsze i bardziej komfortowe (odpowiedzi 8-10 w 10-stopniowej skali Likerta, gdzie 10 oznacza w najwyższym stopniu) Źródto: opracowanie wtasne na podstawie (World Values Survey, 2017)

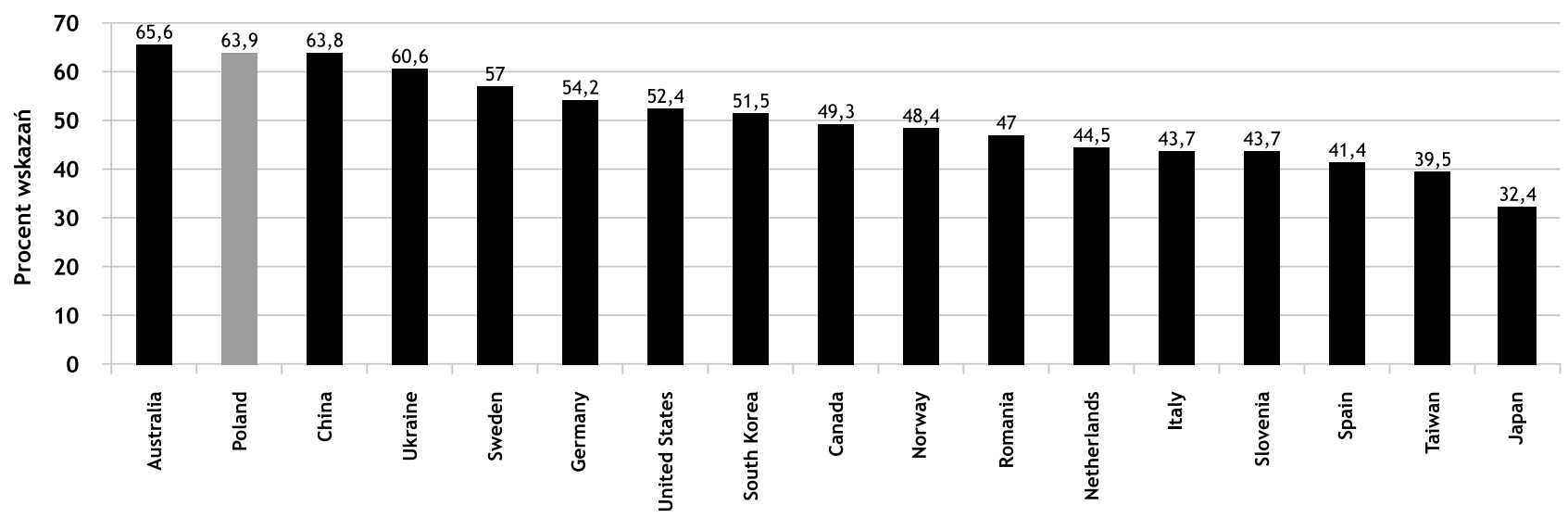

Rys. 5. Procent wskazań odpowiedzi na pytanie: Dzięki nauce i technologii świat jest lepszy (odpowiedzi 8-10 w 10-stopniowej skali Likerta, gdzie 10 oznacza w najwyższym stopniu)

Żródto: opracowanie wtasne na podstawie (World Values Survey, 2017)

\section{Uwarunkowania zaufania do technologii}

Z agadnienie zaufania do technologii staje się szczególnie istotne w dwóch sytuacjach: (i) w sytuacji pojawiania się nowych technologii (emerging technology) lub (ii) w sytuacji gdy dotychczas stosowane technologie nie działają zgodnie z oczekiwaniami i/lub stają się przykładowo źródłem zagrożenia dla człowieka i społeczeństwa.

Zaufanie do technologii, podobnie jak pozostałe kategorie zaufania, jest uwarunkowane przez dwa podstawowe czynniki: ryzyko oraz zależność (Rousseau i in., 1998). Użytkowanie technologii zwłaszcza w okresie dynamicznego ich rozwoju i ograniczonego dostępu do informacji (wynikającego z braku wiedzy) o technologiach (np. skutkach ich stosowania) wiąże się z podejmowanym przez użytkowników technologii ryzykiem. Z drugiej strony człowiek jest w coraz większym stopniu zależny od technologii (Halicka, 2016). Jak wskazuje D.H. McKnight (2005), zaufanie do technologii IT jest szczególnie istotne, bo człowiek polega na tych technologiach jak nigdy przedtem.

Ryzyko najczęściej definiowane jako prawdopodobieństwo wystąpienia zagrożenia i skutków powodowanych przez to zagrożenie, w zależności od obszaru zastoso- wania, znalazło odzwierciedlenie w pojęciach: ryzyko finansowe, ryzyko zawodowe, ryzyko operacyjne, ryzyko rynkowe. Wychodząc z definicji ryzyka operacyjnego, zaproponowanej przez Zawiłę-Niedźwieckiego (2010), autorka proponuje następującą definicję ryzyka związanego z użytkowaniem technologii: ryzyko związane $\mathrm{z}$ użytkowaniem technologii polega na niespełnieniu przez technologię oczekiwań oraz na narażeniu użytkownika na nieoczekiwane (niekontrolowane, nieprzewidywane) ze strony technologii zagrożenia powodujące negatywne skutki. Autorzy O. Renn, Ch. Benighaus (2013) wskazali, że ryzyko i umiejętność jego dostrzegania związane są z pozyskiwaniem i przetwarzaniem sygnałów i informacji dotyczących potencjalnego, szkodliwego oddziaływania technologii oraz gromadzenia na tej podstawie wiedzy dotyczącej szkodliwości, prawdopodobieństwa wystąpienia negatywnych skutków i poziomu akceptowalności technologii.

Relacja pomiędzy ryzykiem a zaufaniem do technologii ma charakter dwustronny. Zaprezentowane na rysunku 6 relacje wskazują na kierunek zależności w dwóch sytuacjach: bez efektu wzmocnienia lub osłabienia, z efektem wzmocnienia lub osłabienia. $Z$ jednej strony relacje oparte na zaufaniu sprzyjają podejmowaniu ryzyka, $\mathrm{z}$ drugiej 
sam fakt narażenia na występujące ryzyka wymusza zaufanie (pętla 1 - rys. 6). Z efektem wzmocnienia mamy do czynienia, gdy w wyniku podejmowanego działania, jak efekt zaufania początkowego, pojawiają się oczekiwane i pożądane rezultaty, które to zaufanie wzmacniają. Efekt osłabienia występuje w sytuacji, kiedy podejmowane działania są źródłem niepożądanych skutków osłabiających zaufanie początkowe (pętla 3).

Drugą ważną determinantą relacji opartych na zaufaniu jest rodzaj relacji między stronami. W stosunkach międzyludzkich relacje te mogą mieć charakter prostej zależności, charakterystycznej dla relacji opartych na przykład na podległości lub współzależności, w której obie strony odczuwają korzyści z relacji. Najłatwiejszym sposobem rozróżnienia relacji zależności jest odniesienie relacji do konkretnych osób. Wyróżnić można zatem trzy sytuacje:

- zależność (dependence) oznaczająca nastawienia na TY;

- niezależność (independence) oznaczająca nastawienia na JA;

- współzależność (interdependence) oznaczająca nastawienia na MY (Pufal, 2017).
Odnosząc wymienione typy zależności do relacji między człowiekiem a technologią (rys. 7), dominującym typem zależności będzie współzależność, gdzie człowiek i jego rozwój są zależne od rozwoju technologii, ale i rozwój technologii jest zależny od człowieka (współzależność). Można również wyobrazić sobie sytuację, w której człowiek jest zależny od technologii, a poziom rozwoju technologii pozostaje bez zmian (zależność). Trzecim typem relacji jest sytuacja, w której technologia rozwija się niezależnie (najczęściej w sposób niekontrolowany). Obecnie trudno sobie wyobrazić sytuację, w której człowiek jest niezależny od jakiejkolwiek technologii.

Uwzględniając fakt występującego ryzyka i zależności człowieka od technologii, człowiek, stosując określoną technologię, musi na niej coraz częściej polegać, oczekując jednocześnie, że prawdopodobieństwo wystąpienia niepożądanych skutków związanych z jej użytkowaniem będzie coraz mniejsze. Innymi słowy, musimy zaufać technologii wierząc w jej funkcjonalność, niezawodność oraz licząc na ewentualną pomoc ze strony technologii.

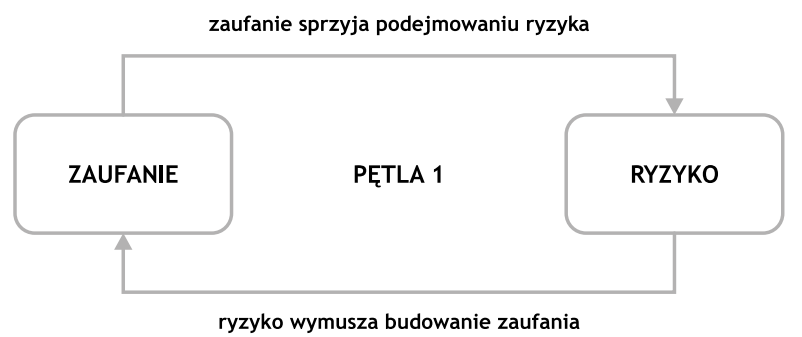

a) pętla 1 bez efektu wzmocnienia lub ostabienia

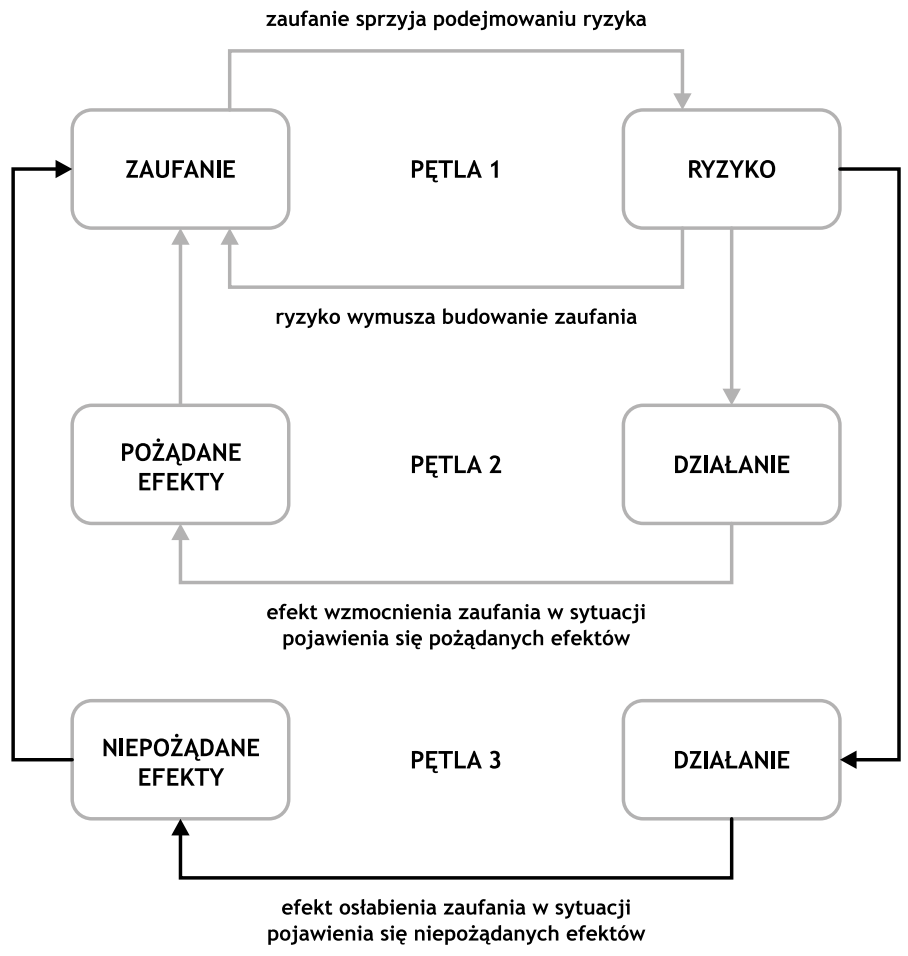

b) pętla 2 i 3 z efektem wzmocnienia i ostabienia

Rys. 6. Wzajemna zależność między zaufaniem a ryzykiem Źródto: opracowanie wtasne 


\section{Determinanty zaufania do technologii}

7 aufanie jako konstrukt pomiarowy jest obiektem zain-

- teresowania $\mathrm{z}$ trzech perspektyw:

- analizy czynników determinujących (trust antecendents) zaufanie do technologii;

- definiowania skal pomiarowych samego zaufania; - analizy wpływu zaufania na inne konstrukty.

Uwzględniając obszerność wskazanych wyżej obszarów problemowych, w artykule podjęto próbę klasyfikacji czynników determinujących zaufanie do technologii. Technologie informacyjno-komunikacyjne (ang. Information and Communication Technologies - ICT) znajdujące zastosowanie w każdej sferze życia społeczno-gospodarczego są w szczególności obiektem zainteresowania badaczy zajmujących się problematyką czynników determinujących zaufanie. Przykładowe badania w obszarze zaufania do technologii dotyczą: elektronicznego wypełniania zeznań podatkowych (Chen i in., 2015), rządowych stron internetowych (Teo i in., 2008; Belanger, Carter, 2008), chmur

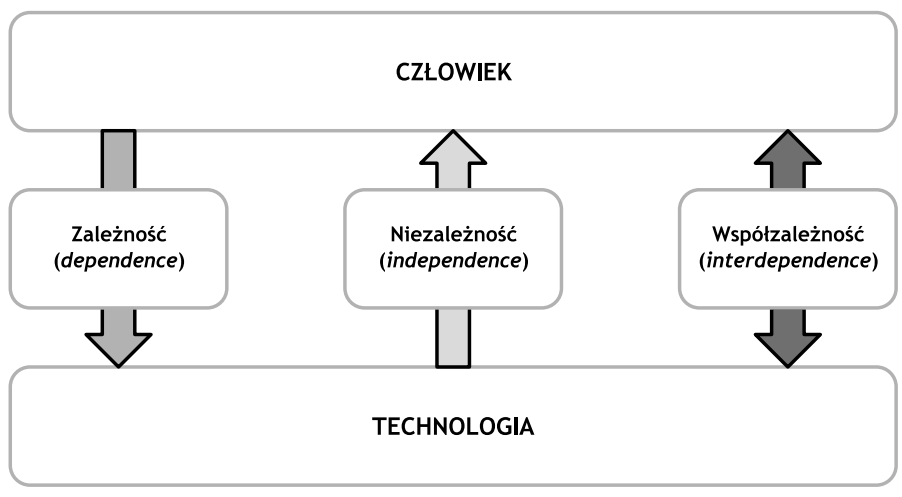

Rys. 7. Typy zależności w relacjach człowiek-technologia Źródto: opracowanie wtasne

Tab. 1. Czynniki determinujace zaufanie do technologii (trust antecendents)

\begin{tabular}{|c|c|c|}
\hline $\begin{array}{l}\text { Nazwa grupy } \\
\text { czynników }\end{array}$ & Opis & Przykłady czynników \\
\hline $\begin{array}{l}\text { Instytucjonalno- } \\
\text {-organizacyjne }\end{array}$ & $\begin{array}{l}\text { Odnoszące się do organizacji stosującej } \\
\text { technologię (bank, szpital) lub instytucji } \\
\text { zarządzającej technologią (Facebook) }\end{array}$ & $\begin{array}{l}\text { zaufanie instytucjonalne } \\
\text { polityka prywatności } \\
\text { wzajemna współzależność między pracownikami } \\
\text { społeczność organizacyjna } \\
\text { kultura organizacyjna } \\
\text { reputacja }\end{array}$ \\
\hline Technologiczne & $\begin{array}{l}\text { Odnoszące się do parametrów techniczno- } \\
\text { technologicznych analizowanej technologii }\end{array}$ & $\begin{array}{l}\text { użyteczność technologii } \\
\text { funkcjonalność technologii } \\
\text { postrzegana łatwość użycia } \\
\text { poziom bezpieczeństwa } \\
\text { gwarancja prywatności } \\
\text { jakość systemu } \\
\text { jakość usług } \\
\text { jakość informacji } \\
\text { ryzyko }\end{array}$ \\
\hline Cechy użytkowników & Odnoszące się do cech użytkowników & $\begin{array}{l}\text { zaufanie interpersonalne } \\
\text { ogólna skłonność do zaufania } \\
\text { zaufanie do technologii podobnych } \\
\text { poziom satysfakcji } \\
\text { wcześniejsze doświadczenia z technologią } \\
\text { znajomość technologii } \\
\text { wiedza o technologii } \\
\text { wykształcenie }\end{array}$ \\
\hline Otoczenie & $\begin{array}{l}\text { Odnoszące się do otoczenia organizacji } \\
\text { stosującej technologię lub do środowiska } \\
\text { zapewniającego funkcjonowanie technologii }\end{array}$ & $\begin{array}{l}\text { reputacja instytucji/organizacji w otoczeniu } \\
\text { zaufanie do instytucji/organizacji } \\
\text { postrzegana przez otoczenie ochrona prywatności } \\
\text { postrzegana przez otoczenie ochrona bezpieczeństwa } \\
\text { społeczna akceptacja technologii } \\
\text { wymagania prawne w zakresie zapewnienia } \\
\text { bezpieczeństwa i prywatności }\end{array}$ \\
\hline
\end{tabular}

Źródto: opracowanie wtasne na podstawie (Lippert, Forman, 2006; Budgol, 2009; Meng i in., 2008; Benlian, Hess; 2011; Xu i in., 2014; Chen $i$ in., 2015; Alzahrani $i$ in., 2017) 
obliczeniowych (Manuel, 2015), oprogramowania (Lankton i in., 2014), mobilnych aplikacji bankowych (Luarn, Juo, 2010), narodowego systemu identyfikacji tożsamości (Li i in., 2008), zaufania do Facebooka (Lankton, McKnight, 2011) czy komunikacji on-line (Benlian, Hess, 2011).

Badania odnoszące się do obszaru związanego $\mathrm{z}$ determinantami zaufania do technologii pozwoliły na próbę klasyfikacji czynników z wyróżnieniem 4 ich grup (tab. 1).

Wskazane w tabeli 1 determinanty zaufania do technologii stanowią dla wielu autorów podstawę budowania teoretycznych modeli zaufania, które w głównej mierze uwzględniają powiązania między wskazanymi czynnikami. Kierunek zależności i siła związku między zmiennymi są uzależnione od rodzaju technologii (np. produktowe, procesowe, hedoniczne, technologie stosowane na zasadzie dobrowolności lub obligatoryjnie). Dobór zmiennych do modeli zaufania do technologii powinien uwzględniać cele naukowe przyjmowane przez badaczy.

\section{Podsumowanie}

B rak jednoznacznej definicji zaufania do technologii wynika z faktu: złożoności, kompleksowości i wieloznaczności samego terminu zaufania, a tym samym zaufania do technologii. Cechy zaufania interpersonalnego (np. uczciwość, wiarygodność, życzliwość) nie mogą być bezpośrednio odniesione do zaufania do technologii z uwagi na materialny charakter technologii. Do cech odzwierciedlających znaczenia terminu zaufania do technologii można zaliczyć: oczekiwaną funkcjonalność, niezawodność oraz system wsparcia ze strony technologii.

Zaufanie do technologii najczęściej wyraża gotowość jednostki do bycia podatnym/pod wpływem technologii, wynikającej z oczekiwanej funkcjonalności, przewidywanej niezawodności oraz indywidualnego upodobania technologii. Przeprowadzone studia literaturowe pozwoliły na wypracowanie autorskiej definicji zaufania do technologii oraz próbę klasyfikacji czynników determinujących zaufanie do technologii. Zaufanie do technologii to wynikająca z postrzeganych właściwości technologii oraz czynników otoczenia skłonność do polegania na technologii, w sytuacji potencjalnego ryzyka związanego z użytkowaniem technologii, determinująca intencje w zakresie przyszłego wykorzystywania technologii. Skłonność do polegania na technologii wynika przede wszystkich $\mathrm{z}$ jej funkcjonalności, niezawodności i systemu wsparcia.

Do głównych czynników warunkujących skalę i siłę relacji opartych na zaufaniu w relacji człowiek-technologia należą ryzyko i stopień zależności człowieka od technologii. Czynniki determinujące zaufanie do technologii można sklasyfikować w obrębie czterech kategorii: czynniki organizacyjno-instytucjonalne, technologiczne, czynniki odzwierciedlające cechy użytkowników oraz czynniki odnoszące się do otoczenia.

Prospektywnymi obszarami badawczymi w zakresie zaufania do technologii wydają się badania, których celem powinno być zdefiniowanie i dobór zmiennych ukrytych i obserwowalnych na potrzeby pomiaru zaufania do różnych typów technologii oraz uwzględnienie w katalogu zmiennych poziomu zależności i ryzyka związanego z użytkowaniem technologii. Ciekawym obszarem zainteresowania badaczy wydaje się badanie czynników (antecedens) i relacji między nimi, determinujących zarówno zaufanie początkowe, jak i zaufanie związane $\mathrm{z}$ użytkowaniem technologii.

$\mathrm{W}$ aspekcie dynamicznego pojawiania się nowych i gwałtownie rozwijających się (expotential) technologii potencjalnym obszarem badawczym jest wskazanie roli zaufania do technologii w kontekście modelu akceptacji technologii (ang. Technology Acceptance Model - TAM).

$\mathrm{Z}$ perspektywy makroekonomicznej istotne mogą być badania nad czynnikami determinującymi zmiany i zróżnicowania poziomu zaufania ogólnego do technologii z perspektywy poszczególnych państw.

dr hab. inż. Joanna Ejdys, prof. PB

Politechnika Biatostocka

Wydziat Inżynierii Zarządzania

e-mail: j.ejdys@pb.edu.pl

\section{Bibliografia}

[1] Alzahrani L., Al-Karaghouli W., Weerakkody V. (2017), Analysing Critical Factor Influencing Trust in E-government Adoption from Citizens' Perspective: A Systematic Review and a Conceptual Framework, „International Business Review”, Vol. 26, No. 1, pp. 164-175.

[2] Belanger F., Carter L. (2008), Trust and Risk in E-government Adoption, „Journal of Strategic Information Systems”, Vol. 17, No. 2, pp. 165-176.

[3] Benlian A., Hess T. (2011), The Signaling Role of IT Features in Influencing Trust and Participation in Online Communities, „International Journal of Electronic Commerce”, Vol. 15, No. 4, pp. 7-56.

[4] Budgol M. (2009), Zaufanie technologiczne, „Ekonomika i Organizacja Przedsiębiorstwa", Nr 11, s. 3-9.

[5] Chen J.V., Jubilado R.J.M., Capistrano E.P.S., Yen D.C. (2015), Factors Affecting Online Tax Filing - An Application of the IS Success Model and Trust Theory, „Computers in Human Behavior", Vol. 43, pp. 251-262.

[6] Ejdys J., Nazarko J., Kononiuk A., Gudanowska A., Glińska E., Glińska U. (2013), Kierunki rozwoju nanotechnologii w województwie podlaskim. Mapy. Marszruty. Trendy, Oficyna Wydawnicza Politechniki Białostockiej, Białystok.

[7] Fukuyama F. (1997), Zaufanie. Kapitat społeczny a droga do dobrobytu, Wydawnictwo Naukowe PWN, Warszawa.

[8] Grudzewski W.M., Hejduk I.K., Sankowska A., Wańtuchowicz M. (2009), Zarządzanie zaufaniem w przedsiębiorstwie. Koncepcje, narzędzi zastosowania, Oficyna a Wolters Kluwer business, Kraków.

[9] Halicka K. (2016), Prospektywna analiza technologii. Metodologia i procedury badawcze, Oficyna Wydawnicza Politechniki Białostockiej, Białystok.

[10] Hiltunen E., Hiltunen K. (2015), Technolife 2035. How Will Technology Change Our Future, Cambridge Scholars Publishing, Cambridge. 
[11] Krot K., Lewicka D. (2016), Zaufanie w organizacji innowacyjnej, Wydawnictwo C.H. Beck, Warszawa.

[12] Lankton N., McKnight D.H., Thatcher J.B. (2014), Incorporating Trust-in-Technology into Expectation Disconfirmation Theory, „Journal of Strategic Information Systems”, Vol. 23, No. 2, pp. 128-145.

[13] Lankton N.K., McKnight H.D. (2011), What Does it Mean to Trust Facebook? Examining Technology and Interpersonal Trust Beliefs, „Data Base for Advances in Information Systems", Vol. 42, No. 2, pp. 32-54.

[14] Larzelere R.E., Huston T.L. (1980), The Dyadic Trust Scale: Toward Understanding Interpersonal Trust in Close Relationships, „Journal of Marriage and the Family”, Vol. 42, No. 3, pp. 595-604.

[15] Li X., Hess T.J., Valacich J.S. (2008), Why do We Trust New Technology? A Study of Initial Trust Formation with Organizational Information Systems, „The Journal of Strategic Information Systems", Vol. 17, No. 1, pp. 39-71.

[16] Lippert S.K. (2001), An Exploratory Study into the Relevance of Trust in the Context of Information Systems Technology, Doctoral Dissertation, The George Washington University, Washington.

[17] Lippert S.K., Forman H. (2006), A Supply Chain Study of Technology Trust and Antecedents to Technology Internalization Consequences, „International Journal of Physical Distribution \& Logistics Management”, Vol. 36, No. 4, pp. 271-288.

[18] Luarn P., Juo W.-J. (2010), The Role of Trust in Technology within the TAM in the Context of NFC Mobile Payment, „Journal of Information and Optimization Sciences”, Vol. 31, No. 4, pp. 875-896.

[19] Luhmann N. (1979), Trust and Power, Wiley, Chichester.

[20] Manuel P. (2015), A Trust Model of Cloud Computing Based on Quality of Service. A Trust Model of Cloud Computing Based on Quality of Service, „Annals of Operations Research”, Vol. 233, No. 1, pp. 281-292.

[21] Mayer R.C., Davis J.H., Schoorman F.D. (1995), An Integrative Model of Organizational Trust, „Academy of Management Review", Vol. 20, No. 3, pp. 709-734.

[22] McKnight D.H. (2005), Trust in Information Technology, [in:] G.B. Davis (ed.), The Blackwell Encyclopedia of Management, Vol. 7: Management Information Systems, Blackwell, Malden.

[23] Meng D., Min Q., Li Y. (2008), Study on Trust in Mobile Commerce Adoption - A Conceptual Model, International Symposium on Electronic Commerce and Security, IEEE Computer Society, IEEE, pp. 246-249.

[24] Nazarko J., Kononiuk A. (2013), The Critical Analysis of Scenario Construction in the Polish Foresight Initiatives, „Technological and Economic Development of Economy", Vol. 19, No. 3, pp. 510-532.

[25] Paliszkiewicz J. (2013), Zaufanie w zarządzaniu, Wydawnictwo Naukowe PWN, Warszawa.

[26] Pufal P., Zależność i wspótzależność [Dokument elektroniczny], http://www.metanoja.pl/zaleznosc-i-wspolzaleznosc/, data dostępu: 11.03.2017 r.

[27] Renn O., Benighaus Ch. (2013), Perception of Technological Risk: Insights from Research and Lessons for Risk Communication and Management, „Journal of Risk Research", Vol. 16, No. 3-4, pp. 293-313.
[28] Rousseau D.M., Sitkin S.B., Burt R.S., Camerer C. (1998), Not So Different After All: A Cross-Discipline View of Trust, „Academy of Management Review”, Vol. 23, No. 3, pp. 393-404.

[29] Ryciuk U. (2016), Zaufanie międzyorganizacyjne w łańcuchach dostaw w budownictwie, Wydawnictwo WNT, Warszawa.

[30] Sankowska A. (2015), Analiza zaufania w sieciach badawczo-rozwojowych, Wydawnictwo Naukowe PWN, Warszawa.

[31] Słownik Języka Polskiego (2006), Wydawnictwo Naukowe PWN, Warszawa.

[32] Sztompka P. (2007), Zaufanie. Fundament społeczeństwa, Znak, Kraków.

[33] Teo T.S.H., Srivastava S.C., Jiang L. (2008), Trust and Electronic Government Success: An Empirical Study, „Journal of Management Information Systems", Vol. 25, No. 3, pp. 99-131.

[34] Wasiluk A., Suchocki A. (2012), Zaufanie jako bariera rozwoju przedsiębiorstw handlu elektronicznego, „Ekonomia i Zarządzanie", Nr 4(1), s. 113-123.

[35] Wielki Słownik Języka Polskiego, Instytut Języka Polskiego PAN, http://wsjp.pl/index.php?id_hasla=3199\&ind=0\&w_szukaj=zaufanie, data dostępu: 30.12.2016 r.

[36] World Values Survey, http://www.worldvaluessurvey.org/wvs. jsp, access date: 27.05.2017.

[37] Xu J., Le K., Deitermann A. (2014), How Different Types of Users Develop Trust in Technology: A Qualitative Analysis of the Antecedents of Active and Passive User Trust in a Shared Technology, „Applied Ergonomics”, Vol. 45, No. 6, pp. 1495-1503.

[38] Zawiła-Niedźwiecki J. (2010), Pojęcie ryzyka operacyjnego i klasyfikacja jego rodzajów, „Przegląd Organizacji”, Nr 6, s. 19-21.

\section{Antecedents of Technology Trust}

\section{Summary}

Initially, relationships were based on trust and had interpersonal nature, i.e. occurred between two or more people (interpersonal trust). Over time, the concept of trust was applied to institutions/organisations (institutional trust, organisational trust), things, devices, and technologies (technology trust). The dynamic development of technology and the growing human dependence on technology raises the interest of researchers in technology trust, their attempt to operationalize this notion and searching for an answer to the following questions: How to define technology trust, What determines technology trust? What are technology trust antecedents? And how to measure them? How to manage technology trust?

In this article, the Author attempts to define technology trust, describes two key conditions that require technology trust (risk and dependency), and indicates the antecedents of technology trust. The basic research method applied was literature review and critical literary analysis. A review of the literature allowed to indicate potential research areas.

\section{Keywords}

trust, technology trust, technology trust antecedents 